\title{
PENGARUH MODAL INTI TERHADAP PROFITABILITAS DAN KINERJA PERBANKAN (STUDI PADA BANK SYARIAH DI INDONESIA)
}

\author{
Kristiningsih 1 , * \\ Program Studi Manajemen, Universitas Wijaya Kusuma Surabaya, Indonesia \\ kristiningsih@uwks.ac.id \\ *Corresponding author \\ Ruswiati ${ }^{2}$ \\ Program Studi Manajemen, Universitas Wijaya Kusuma Surabaya, Indonesia \\ ruswiati@gmail.com
}

\begin{abstract}
Background - The growth potential of sharia banking business in Indonesia is increasing, so it is important to evaluate the performance of sharia banking

Aim - This study aims to examine the effect of core capital on the profitability and performance of Islamic Commercial Banks listed on the

Diterima : 13 Januari 2022 Direview : 14 Januari 2022 Direvisi : 21 Januari 2022

Disetujui : 31 Januari 2022
\end{abstract} Indonesia Stock Exchange. This research is expected to provide input in financial knowledge, especially in the field of evaluating bank financial performance and the factors that influence it.

Design/ Methodology/ Approach - The research object is 12 Islamic banks in Indonesia. The data is taken from the financial statements of each Islamic bank from 2015 to 2018. Hypothesis testing is carried out using a structural equation model with the WARP PLS program.

Results and Discussion - The results show that core capital has a significant effect on profitability, as well as profitability has a significant effect on core capital. The results also show that core capital has no effect on performance and performance has no significant effect on core capital. The results showed that profitability had no effect on performance.

Conclusion - The results of this study conclude that of the five hypotheses proposed only two are accepted, namely core capital has a significant effect on profitability, and vice versa profitability also has a significant effect on core capital. This study produces evidence that core capital has no significant effect on the performance of Islamic banks. Likewise, it turns out that profitability also does not significantly affect the performance of Islamic banks, but on the contrary, the performance of Islamic banks has no significant effect on profitability.

Research implications - for the Islamic banking business, this research can provide input on how to measure the performance of Islamic banks through the profitability and core capital of Islamic banks. The object of research is 12 Islamic banks in

Limitations of the study - The research was carried out during the period when Islamic banks in Indonesia had not been merged

Keywords - Core, Capital, Profitability, Performance

\begin{abstract}
Abstrak
Latar Belakang - Potensi pertumbuhan bisnis perbankan syariah di Indonesia makin meningkat, sehingga penting dilakukan evaluasi terhadap kinerja perbankan syariah

Tujuan - Penelitian ini bertujuan untuk menguji pengaruh modal inti terhadap profitabilitas dan kinerja Bank Umum Syariah yang terdaftar di Bursa Efek Indonesia. Penelitian ini diharapkan dapat
\end{abstract}


memberikan masukan dalam pengetahuan keuangan khususnya dalam bidang evaluasi kinerja keuangan bank dan faktor-faktor yang mempengaruhinya.

Desain/ Metodologi/ Pendekatan - Objek penelitian adalah 12 bank syariah di Indonesia. Data diambil dari laporan keuangan masing-masing bank syariah dari tahun 2015 hingga 2018. Uji hipotesis dilakukan dengan structural equation model denngan program WARP PLS.

Hasil dan Pembahasan - Hasil penelitian menunjukkan bahwa Modal Inti berpengaruh signifikan terhadap profitabilitas, begitu pula profitabilitas berpengaruh signifikan terhadap modal inti. Hasil penelitian juga menunjukkan bahwa modal inti tidak berpengaruh terhadap kinerja dan kinerja tidak berpengaruh signifikan terhadap modal inti. Hasil penelitian menunjukkan bahwa profitabilitas tidak berpengaruh terhadap kinerja.

Kesimpulan - Hasil penelitian ini menyimpulkan bahwa dari lima hipotesis yang diajukan hanya dua yang diterima yaitu Modal inti berpoengaruh signifikan terhadap rofitabilitas, dmikian sebaliknya profitabilitas juga berpengaruh signifikan terhadap modal inti. Penelitian ini menghasilkan bukti bahwa modal inti tidak berpengaruh signifikan terhadap kinerja bank syariah. Demikian juga ternyata Profitabilitas juga tidak signifikan mempengaruhi kinerja bank syariah, namun sebaliknya kinerja bank syariah tidak berpengaruh signifikan terhadap profitabilitas.

Implikasi penelitian - implikasi manajerial terhadap bisnis perbankan syariah, penelitian ini dapat memberikan masukan tentang bagaimana mengukur kinerja bank syariah melalui profitabilitas dan modal inti bank syariah. Objek penelitian adalah 12 bank syariah di Indonesia

Batasan penelitian - Penelitian dilakaukan dalam kurun waktu Ketika bank syariah di Indonesia belum dimerjer

Keywords - Modal, Inti, Profitabilitas, Kinerja

\section{PENDAHULUAN}

Kinerja keuangan dalam sebuah bank, penting dievaluasi sebagai dasar dalam membuat kebijakan yang rasional. Kinerja keuangan tersebut dapat dinilai dari berbagai komponen seperti hal yang berkaitan dengan operasional bank, keuangan, sumber daya, pemasaran maupun teknologi informasi. Setiap bank diwajibkan membuat laporan keuangan dari seluruh aktivitasnya seperti aturan Pedoman Standar Akuntansi Perbankan Indonesia yang dikeluarkan oleh Bank Indonesia. Ada perbedaan yang cukup signifikan dalam mnegukur kinerja keuangan antara bank konvensional dan Bank syariah (Amelia \& Nugrahani, 2018). Penilaian pada kinerja perbankan syariah dapat dinilai dari pendekatan parameter book value, price earning ratio, dan harga saham.

Ketika perbankan memiliki profitabilitas yang baik maka akan menimbulkan kinerja yang baik yang ditunjukkan dari nilai Price earning ratio (PER). Price earning ratio menggambarkan rasio perbandingan harga saham terhadap earning saham. Semakin tinggi nilai PER menunjukkan makin baik kinerja perusahaan tersebut. Semakin tinggi nilai profitabilitas, maka akan meningkatkan kinerja keuangan perusahaan (Fathurrahman, 2012). Penelitian lain juga menyatakan bahwa Modal inti dan Profitabilitas bank berpengaruh sihnifikan terhadap kinerja perbankan (Naseer, 2019). Indonesia 
merupakan Negara dengan penduduk muslim terbesar di dunia (Indonesia Investment, 2020) Lebih lanjut dikatakan bahwa penduduk negara Indonesia beragama Islam, Hal ini yang membuat Indonesia menjadi pasar potensial yang penting dalam mengembangkan produk/jasa keuangan syariah. Pada masa ini, industri jasa keuangan syariah sgresif melakukan edukasi dan sosialisasi tentang peranan bank syariah yang dapat menimbulkan kedaran (awareness) dan keinginan masyarakat luas untuk menggunakan jasa perbankan syariah.

Ada perbedaan yang cukup berarti antara mekanisme dalam perbankan syariah dibandingkan perbankan konvensional. Unsur utama yang membuat berbeda adalah pemenuhan kepatuhan terhadap nilai-nilai syariah (shariah compliance) dari masyarakat terhadap aturan agama Islam. Perbedaan ini merupakan keutamaan dari bank syariah dibanding bank konvensional, karena sistem yang diterapkan mampu menjamin penerapan nilai-nilai syariah yang diajarkan dalam agama Islam (Mardian, 2015).

Mengacu pada Laporan Statistik Perbankan Syariah OJK (Juni-2016), bahwa untuk saat ini ada dua belas Bank Umum Syariah di Indonesia. Walaupun aset perbankan syariah masih bekisar pada angka lima persen dari semua aset perbankan nasional, namun terdapat potensi untuk bertumbuh pada industri perbankan syariah yang diduga mengalami kenaikan. Karena alasan tersebut, maka perlu dilakukan evaluasi pada kinerja perbankan syariah. Walaupun sistem ini dianggap baru, penting untuk belajar berdasarkan pengalaman sebelumnya guna memperbaiki kinerja yang lalu dan melakukan perbaikan dengan cara yang nyata dan rasional. Penting untuk menilai kinerja Perbankan Sharia dengan beberapa pendekatan (Ongera \& Ndede, 2019). Hal ini lah yang menjadikan fenomena gap mengapa pengukuran kinerja bank Syariah perlu dikaji lebih lanjut.

Semenjak tahun 2012, Bank Indonesia sudah menetapkan peraturan yang membagi bank dalam 4 (empat) klaster. Peraturan ini kemudian diperbaharui oleh Peraturan Otoritas Jasa Keuangan Nomor 6/POJK.03/2016 tentang Kegiatan Usaha dan Jaringan Kantor Berdasarkan Modal Inti Bank. Dalam peratuan tersebut, yang perlu digaris bawahi adalah aturan mengenai pengelompokan Bank berdasarkan kegiatan usaha sesuai dengan besarnya modal inti. Pengelompokan ini disebut sebagai Bank Umum berdasarkan Kegiatan Usaha (BUKU). Peraturan ini berlaku untuk semua bank, baik bank umum, bank syariah maupuan unit usaha syariah.

Bank Indonesia mengutamakan nilai profitabilitas diukur dari nilai ROA nya yang 
dananya sebagian besar berasal dari masyarakat (Lukman, 2003). Semakin tinggi nilai Rasio CAR, maka semakin baik permodalan bank, dan akan berguna untuk meningkatkan trust dari masyarakat. Kapital yang besar akan dapat meningkatkan laba. Salvatore (2005) menyatakan bahwa bank akan mengandalkan return earning untuk meningkatkan kapital. Dengan demikian ROE akan berpengaruh positif terhadap CAR. Komponen Modal penting dalam perbankan karena akan mendukung kegiatan operasional bank (Ernasari, 2017). Jika CAR suatu bank di atas ketentuan yang berlaku, maka kepercayaan masyarakat akan meningkat dan hal ini akan meningkatkan harga saham bank tersebut, dengan demikian kinerja keuangan bank menjadi meningkat.

Penelitian ini bertujuan untuk menguji pengaruh modal inti terhadap profitabilitas dan kinerja Bank Syariah yang terdaftar pada Bursa efek Indonesia. Pada beberapa penelitan sebelumnya pengukuran dilakukan dengan bersifat kausal recursif, artinya menguji hubungan sebab akibat dari profitabilitas terhadap kinerja (Fathurrahman, 2012), modal inti terhadap kinerja, dan modal inti terhadap profitablitas. Untuk tujuan menganalisis lebih dalam variabel variabel dalam penelitian ini, maka penelitian ini mencoba meneliti uji timbal balik (irecursif) antar variabel modal inti terhadap kinerja, modal inti terhadap profitabilitas, selain menguji profitabilitas terhadap kinerja, yang menjadikan perbedaan (gap research) dibanding dengan penelitian yang sudah ada.(Kiambati, 2019); (Naseer, 2019); (William, 2013). Penelitian ini diharapkan memberikan masukan bagi dunia pengetahuan keuangan khususnya di bidang penilaian atas kinerja keuanagan perbankan dan faktor faktor yang mempengaruhinya. Sedangkan implikasi manajerial bagi pelaku bisnis perbankan syariah, penelitian ini dapat memberi masukan tentang faktor faktor yang mempengaruhi kinerja bank syariah melalui profitabilitas dan modal inti dari bank syariah tersebut.

\section{TINJAUAN PUSTAKA}

\section{Modal Inti}

Modal inti dari bank adalah komponen penting dalam membiayai segala aktifitas operasional bank, sebagai cadangan dari kerugian yang mungkin terjadi, dan menjaga tingkat kepercayaan masyarakat terhadap kredibilitas bank tersebut. Modal inti terdiri dari Capital Adequacy ratio (CAR), modal inti utama dan modal inti tambahan. Sebuah bank harus mempunyai capital yang disebut sebagai Modal Inti. Modal Inti modal yang terdiri dari dua komponen yaitu: modal yang disetor dan cadangan-cadangan yang berasal dari laba usaha setelah dikurangi pajak. Selain itu, modal inti juga 
diperoleh dari keuntungan usaha yang didapatkan bank dari hasil usahanya setelah dikurangi dengan pajak. Komponen modal inti pada dasarnya terdiri atas modal disetor dan cadangan-cadangan yang dibentuk dari laba setelah pajak (Ifham, 2010).

\section{Profitabilitas}

Profitabilitas adalah kemampuan suatu bank dalam mendapatkan keuntungan/profit dari penggunaan modalnya (Soebiantoro, 2007). Nilai Profitabilitas ditentukan dari diukur dari net interest margin, yaitu ROA dan ROE. Untuk mendapatkan marjin bunga bersih diperoleh dari selisih antara pendapatan bunga yang diperoleh bank dan nilai bunga yang dibayarkan kepada pemberi pinjaman (berupa deposito).

Ukuran profitabilitas biasanya dinyatakan dalam bentuk prosentase dari nilai pinjaman yang diperoleh dalam periode waktu dan aset lainnya dikurangi dengan nilai bunga atas dana pinjaman dibagi nilai rata-rata dari aktiva tetap pada pendapatan yang diperoleh kurun waktu tersebut. Dalam konteks bank syariah dimana tidak ada unsur bunga dalam operasional ban, maka interest marjin didapatkan dari perhitungan pendapatan bersih dibagi dengan aktiva produk. Mengukur nilai ROA sebagai pengukur nilai profitabilitas, yang menunjukkan kemampuan perusahaan untuk memperoleh keuntungan yang berasal dari aktiva yang digunakan. ROA ini dapat mengindikasikan kemampuan perusahaan memperoleh keuntungan pada masa lalu yang diproyeksikan pada periode mendatang.

ROE merupakan nilai yang mengindikasikan kemampuan perusahaan dalam memperoleh laba bersih dengan mengoptimalkan modal sendiri dan menghasilkan laba bersih yang diperuntukkan bagi pemilik atau investor. ROE tergantung pada ukuran perusahaan, dengan demikian perusahaan dengan ukuran kecil yang mempunyai modal relatif kecil, akan memiliki nilai ROE yang rendah, sebaliknya untuk untuk perusahaan besar maka akan memiliki ROE yang lebih baik. ROE merupakan imbal hasil dari laba bersih atas ekuitas dan dinyatakan dalam bentuk prosen. ROE ini efektif untuk mengukur seberapa mampu bank menghasilkan laba dengan yang berasal dari investasi yang disetorkan oleh pemegang saham. Untuk mengukur ROE dengan membandingkan laba bersih setelah dikurangi pajak dengan ekuitas yang diperoleh dari pemegang saham perusahaan tersebut (Van Horne, 2005). Rasio ini dapat dipakai untuk membandingkan dua buah bak atau perusahaan untuk menentukan mana yang lebih efektif dalam mengelola biaya dan memberikan peluang investasi yang lebih baik. 


\section{Kinerja Bank}

Penilaian pada kinerja perbankan syariah dapat dinilai dari pendekatan parameter book value, price earning ratio, dan harga saham. Book value adalah nilai saham yang dibukukan berdasar biaya atau harga historis (Darmadji, Tjiptono, 2001). Sebagai indikator fundamental dari sebuah saham digunakan harga buku saham atau dikenal dengan price per book value (PBV) yang biasanya dipergunakan oleh investor dan para penganalisa sebagai tolok ukur dari nilai wajar saham. Indikator untuk menentukan nilai ini diperoleh dengan cara membagi harga saham yang didapatkan dari pasar saham dengan nilai book value dari saham yang dinilai. Saham dikatakan memiliki nilai valuasi tinggi, apabila memiliki rasio PBV yang besar, sebalinya apabila saham memiliki valuasi yang rendah/ undervalue, jika memiliki rasio PBV kurang dari satu (Darmadji, Tjiptono, 2001).

Ukuran lain yang dipakai untuk menilai kinerja bank adalah Price earning ratio, yaitu ukuran kinerja yang didapatkan dari membandingkan harga pasar saham dengan pendapatan per lembar sahamnya. Price To Earning Ratio, atau disingkat P/E Ratio merupakan alat yang dipakai untuk menghitung harga saham dengan pemdapatan perusahaan. Hasil ini dapat diartikan sebagai tingkat se berapa besar investor mau membayar setiap rupiah atas pendapatan bank tersebut. Biasanya, investor tetarik membeli saham dengan nilai $\mathrm{P} / \mathrm{E}$ Ratio rendah. Semakin rendah $\mathrm{P} / \mathrm{E}$ Ratio suatu saham, semakin murah harga saham tersebut berkaitan dengan pendapatan perusahaan (Sulistyastuti, 2005). Sedangkan harga saham adalah merupakan harga atau nilai uang yang bersedia dikeluarkan untuk memperoleh saham (Widoatmodjo, 2009). Selanjutnya, harga Saham ini bisa juga dipakai sebagai cara untuk mengukur kinerja keuangan perbankan (Ernasari, 2017).

\section{Hipotesis}

Bank Indonesia mengutamakan nilai profitabilitas diukur dari nilai ROA nya yang dananya sebagian besar berasal dari masyarakat (Dendawijaya, 2015). Rasio CAR yang tinggi menunjukkan semakin baik permodalan bank sehingga akan meningkatkan kepercayaan masyarakat. Modal yang besar dapat meningkatkan laba. Sebaliknya Salvarcy (2011) umumnya bank akan mengandalkan laba ditahan untuk meningkatkan modal.

ROE akan berpengaruh positif terhadap CAR. Apabila nilai CAR (Capital adequcy ratio) memiliki nilai di atas ketentuan minimal yang berlaku, akan berdampak pada meningkatnya tingkat kepercayaan investor pada bank tersebut dan hal ini akan menguntungkan karena dapat meningkatkan harga saham (Haryetti, 2012). Dalam penelitian lain Al-Tamimi KAM (2013) menyatakan bahwa semakin 
baik kinerja bank maka tingkat kepercayaan menggunakan produk bank akan semakin baik yang mengakibatkan setoran masyarakat sebagai komponen modal inti juga meningkat. Hubungan modal inti dengan profitabilitas juga didukung oleh penelitian lain (William, 2013).

H1. Modal inti berpengaruh signifikan pada profitabilitas

H2. Profitabilitas berpengaruh signifikan pada modal inti

Jika suatu bank dapat mencapai Capital adequcy ratio di atas ketentuan yang berlaku, akan meningkatkan kepercayaan investor terhadap bank tersebut dan pada akhirnya berdampak pada kenaikan harga saham. (Haryeti, 2012). Hubungan antara Modal inti dan kinerja didukung oleh penelitian (Amelia \& Nugrahani, 2018) yang menyatakan bahawa struktur kapital berpengaruh terhadap kinerja perbankan.
Selanjutnya At Tamimi dan Obeidat (2013) menyatakan bahwa semakin baik kinerja bank maka tingkat kepercayaan menggunakan produk bank akan semakin baik yang mengakibatkan setoran masyarakat sebagai komponen modal inti juga meningkat

H3. Modal Inti berpengaruh signifikan pada kinerja bank

H4. Kinerja berpengaruh signifikan pada modal inti

Ketika perbankan memiliki profitabilitas yang baik maka akan menimbulkan kinerja yang baik yang ditunjukkan dari nilai PER. Price earning ratio menggambarkan rasio perbandingan harga saham terhadap earning saham. Semakin tinggi nilai PER menunjukkan makin baik kinerja perusahaan tersebut.

H5: Profitabilitas berpengaruh signifikan terhadap kinerja

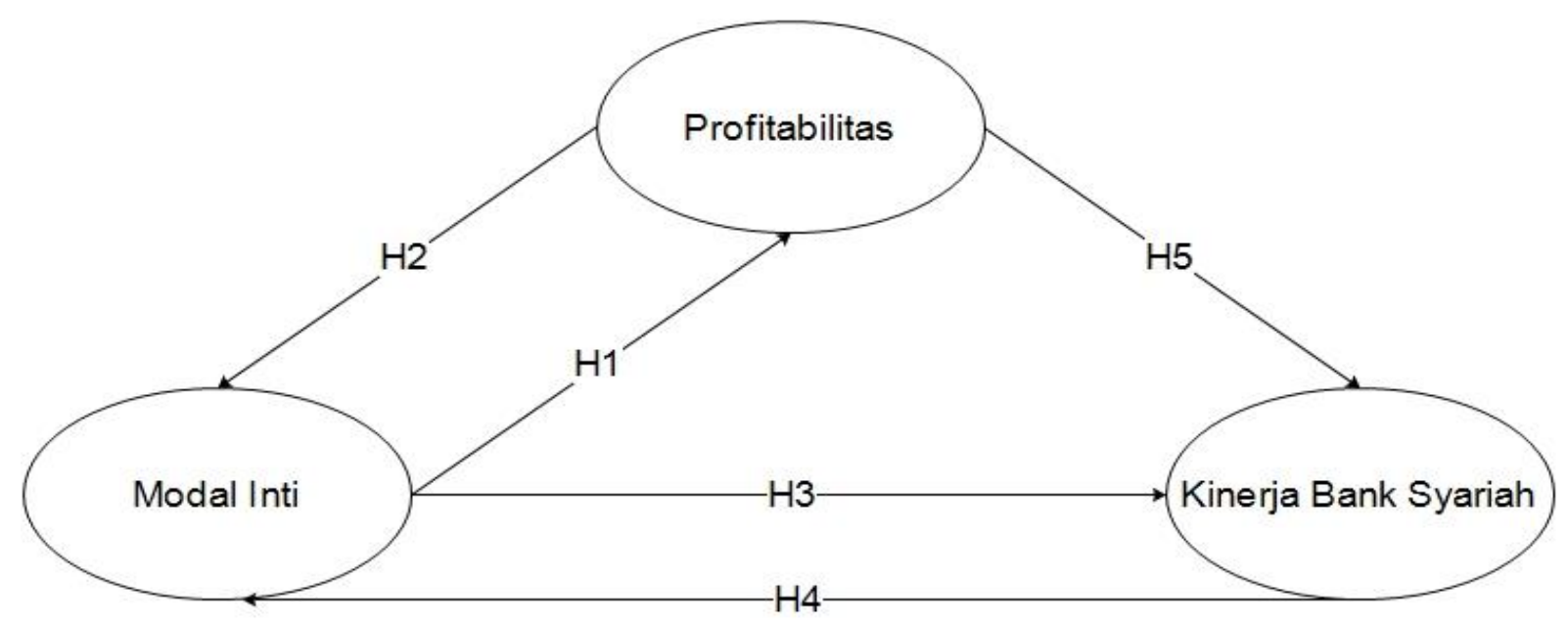

Gambar 1

Kerangka Penelitian 


\section{METODOLOGI PENELITIAN}

Pengujian hipotesis penelitian digunakan pendekatan kuantitatif. Penelitian kuantitatif adalah penelitian yang menekankan analisisnya pada data yang bersifat kuantitatif yang berupa angka numerik yang diperoleh dengan pengolahan data statistik dengan melakukan uji statistik inferensial dalam rangka menguji hipotesis penelitian, yang pada akhirnya akan diperoleh signifikansi hubungan antara variabel yang diteliti. Penelitian ini termasuk kategori penelitian konklusif karena menguji hipotesis dari hubungan antara variabel yang diteliti. Desain penelitian ini merupakan penelitian explanatory yang bermaksud menjelaskan variabel variabel yang diteliti. Penelitian ini menggunakan pendekatan kausal yaitu suatu penelitian yang dilakukan untuk menggambarkan hubungan sebab akibat yang lebih dalam dari dua atau lebih variabel yang diteliti (Sugiyono, 2017).

Populasi dalam penelitian ini adalah seluruh bank syariah yang terdaftar di bursa efek Indonesia pada tahun 20152018. Teknik sampling menggunakan purposive sampling, yaitu pengambilan sampel berdasar kriteria ; Bank syariah tersebut telah menerbitkan laporan keuangan untuk periode penelitian dari tahun 2015 sampai 2018. Ada dua belas Bank Syariah yang akan dianalisis pada penelitian ini : BNI Syariah, Bank Jabar banten syariah, BRI syariah, Bank Tabungan Pensiunan Syariah, Bank Mega Syariah, Bank Victoria Syariah, Maybank Syariah, Bank Muamalat, Bukopin Syariah, Bank Panin Syariah, Bank Syariah Mandiri dan BCA Syariah.

Variabel variabel dalam penelitian ini didefinisioperasionalkan sebagai berikut :

1. Variabel eksogen (Modal inti)

Adalah penyediaan modal yang harus dipenuhi untuk menunjang kegiatan operasional bank syariah, terdiri dari :

a. Modal inti utama; dihitung berdasarkan rasio dari KPMM peraturan bank Indonesia

b. Modal inti tambahan : minimal 2,5\% dari ATMR

ATMR = aktiva tertimbang menurut resiko, KPMM=kewajiban penyertaan modal minimum

Penggunaan dua jenis pengukuran ini mempertimbangkan pada teori yang mendasari dengan ketersediaan data yang ada pada website bank syariah tersebut

2. Variabel endogen 1 (Profitabilitas)

Adalah kemampuan bank syariah menghasilkan laba dengan indikator :

$$
\begin{aligned}
& \text { ROA }=\frac{\text { Laba bersih sebelum pajak }}{\text { Total Aset }} \times 100 \% \\
& \text { ROE }=\frac{\text { Net Income After Tax }}{\text { Share Holder Equity }} \times 100 \%
\end{aligned}
$$

Interest Income $=$

Pendapatan Sebelum dipotong Pajak 
Penggunaan 3 pengukuran untuk mengukur profitabilitas mempertimbangkan ketersediaan data laporan keuangan dari masing masing bank syariah yang diteliti.

3. Variabel endogen 2 (Kinerja)

Adalah kinerja keuangan dari bank syaraiah, yang diukur dengan indikator:

$$
\text { PBV }=\frac{\text { Harga Pasar Saham }}{\text { Nilai Buku Perlembar Saham }}
$$

$$
\text { PER }=\frac{\text { Harga Pasar Saham }}{\text { Laba Bersih Perlembar Saham }}
$$

Data dalam penelitian ini menggunakan data sekunder yang diambil dari laporan keuangan Bank Syariah pada bursa Efek Indonesia pada periode penelitian 20152018. Empat tahun terakhir ini adalah diambil dengan pertimbangan kelengkapan data yang disediakan oleh publikasi pihak bank syariah. Data dikumpulkan melalui dokumentasi pada Laporan Keuangan masing masing bank yang dipublikasikan pada website masing masing bank syariah yang diteliti.

\section{HASIL DAN PEMBAHASAN}

\section{Hasil Penelitian}

Penelitian ini menggunakan dokumentasi dari data Website Bank Syariah dari 12 Bank syariah yang telah menerbitkan laporan keuangan untuk periode penelitian dari tahun 2015 sampai 2018. Ada dua belas Bank Syariah yang dianalisis pada penelitian ini (1) BTPN Syariah, (2) BNI Syariah, (3) BCA Syariah, (4) Maybank Syariah, (5) Bank Mandiri Syariah, (6) BRI Syariah, (7) bank Panin Syariah, (8) Bukopin Syariah, (9) Bank Muamalat, (10) Bank Jabar banten Syariah, (11) Bank Victoria Syariah, dan (12) Bank Mega Syariah.

Tahap pertama dalam pengujian penelitiaan ini adalah dengan menguji validitas dan reliabilitas. Menurut Abdillah W (2015), ukuran validitas diperoleh dari nilai convergent validity (outer model) dengan ketentuan loading factor berkisar antara 0,50 - 0,60. Apabila nilai skor loading antara $0,5-0,7$, maka peneliti tidak perlu menghapus indikator yang memiliki skor loading tersebut sepanjang skor AVE dan communality indikator tersebut di atas 0,5.

Berdasarkan tabel 1 dapat diketahui bahwa semua indikator dalam penelitian ini memenuhi prasyarat validitas konvergen yang mana semua indikator signifikan karena memiliki nilai signifikansi $p$ di bawah 0,05 serta nilai Average Variance Extracted (AVE) lebih dari 0,50 maka dikatakan memenuhi kriteria yang ditentukan.

Indikator dikatakan valid apabila memiiki nilai Average Variance Extracted (AVE) harus diatas 0,50. Tampilan nilai AVE bisa dilihat pada tabel 2 . Tabel 2 mengindikasikan bahwa nilai Average Variance Extracted (AVE) yang didapatkan 
pada ketiga konstruk sudah sesuai dengan

kriteria yang ditetapkan yaitu diatas 0,50

Tabel 1

Output Combinne Loading And Cross Loading

\begin{tabular}{lrrrrr} 
& Modal Inti & Profitabilitas & \multicolumn{1}{c}{ Kinerja } & SE & P Value \\
modal inti utama & 0,927 & $-0, .107$ & 0,036 & 0,100 & $<0,001$ \\
modal inti tambahan & 0,927 & 0,107 & $-0, .036$ & 0,100 & $<0,001$ \\
\hline ROA & $-0,032$ & 0,922 & $-0,014$ & 0,101 & $<0,001$ \\
ROE & 0,031 & 0,969 & 0,032 & 0,099 & $<0,001$ \\
NI & $-0,000$ & 0,989 & $-0, .018$ & 0,098 & $<0,001$ \\
PBV & 0,001 & 0.002 & 1,00 & 0,098 & $<0,001$ \\
PER & $-0,001$ & $-0,002$ & 1,00 & 0,098 & $<0,001$ \\
\hline
\end{tabular}

Sumber : Data dokumentasi Bank Syariah, 2021

Tabel 2

Average Variance Extracted (AVE)

\begin{tabular}{ccc} 
Modal Inti & Profitabilitas & Kinerja \\
0,860 & 0.923 & 0.999 \\
\hline
\end{tabular}

Tahap berikutnya dalam pengujian penelitian adalah menguji hubungan antar variabel laten dalam model penelitian. Hasil uji ini dapat dilihat dari angka estimasi koefisien jalur (path coefficients) dan tingkat signifikansinya (p-value), dalam penelitian ini tingkat signifikansi yang digunakan adalah 5\%. Gambar hasil estimasi untuk melihat hubungan antarvariabel laten dapat dilihat pada gambar 1 dan gambar 2 .

Penelitian ini menggunakan 2 model karena di WarpPLS 6.0 tidak bisa di uji secara bersamaan sehingga harus menggunakan 2 model untuk mengetahui hasilnya. Pengujian pada hipotesis penelitian yang diajukan, ditentukan dari besarnya p-value. Apabila nilai p-value kurang dari 0,05 maka dikatakan tidak ada pengaruh yang signifikan antar variabel yang diujikan. Hasil penelitian yang dilakukan menunjukkan bahwa modal inti terhadap profitabilitas memiliki nilai signifikansi sebesar 0,001 atau nilai signifikansi kurang dari 0,05. Berdasarkan angka signifikansi tersebut, dapat dinyatakan bahwa modal inti berpengaruh signifikan pada profitabilitas, sehingga hipotesis pertama diterima. Penelitian ini menunjukkan bahwa semakin tinggi permodalan bank dapat meningkatkan kepercayaan masyarakat pada bank tersebut. Modal yang besar dapat meningkatkan laba. Hasil penelitian yang dilakukan menunjukkan bahwa modal inti terhadap kinerja keuangan memiliki nilai signifikansi sebesar 0.124 atau nilai 
signifikansi lebih dari 0,05. Berdasarkan hasil tersebut dapat disimpulkan bahwa modal inti tidak berpengaruh signifikan pada kinerja, sehingga hipotesis 3 ditolak. Penelitian ini menunjukkan bahwa modal inti yang besar tidak menentukan kinerja perbankan syariah di Indonesia.

Hasil penelitian yang dilakukan menyatakan nilai signifikansi antara profitabilitas terhadap kinerja memiliki angka sebesar 0.062 dimana nilai tersebut lebih dari 0,05. Berdasarkan hasil tersebut dapat dinyatakan bahwa kinerja tidak berpengaruh signifikan pada modal inti, maka hipotesis kelima dari penelitian

ditolak. Penelitian ini menunjukkan bahwa laba dari suatu perusahaan tidak berpengaruh terhadap kinerja pelayanan dari perusahaan tersebut. Penelitian ini juga menguji hubungan kausal antara profitabilitas berpengaruh signifikan terhadap modal inti, ternyata memiliki nilai signifikansi sebesar 0.038 dimana nila tersebuti kurang dari 0,05. Maka Penelitian ini mengindikasikan bahwa profitabilitas berpengaruh signifikan pada modal inti, sehingga hipotesis kedua diterima. Penelitian ini menunjukkan semakin baik laba perusahaan maka modal inti suatu perusahaan tersebut akan meningkat. Arah hubungan bersifat positif artinya semakin besar profitabilitas akan semakin besar pula modal inti perbankan syariah. Untuk membuktikan hipotesis keempat dalam penelitian ini dapat dilihat dari nilai Path Coeficient antara kinerja dengan modal inti. Ternyata memiliki nilai signifikansi sebesar 0.133 atau nilai signifikansi lebih dari 0,05. Maka penelitian ini mengindikasikan bahwa bahwa kinerja tidak berpengaruh signifikan pada modal inti, artinya hipotesis keempat ditolak. Penelitian ini menunjukkan bahwa kinerja bank tidak berpengaruh terhadap modal inti perbankan. Untuk memudahkan tampilan hasil penelitian, maka hasil penelitian ini dapat diringkas dalam tabel estimasi path coefficient yang tertera dalam tabel 3.

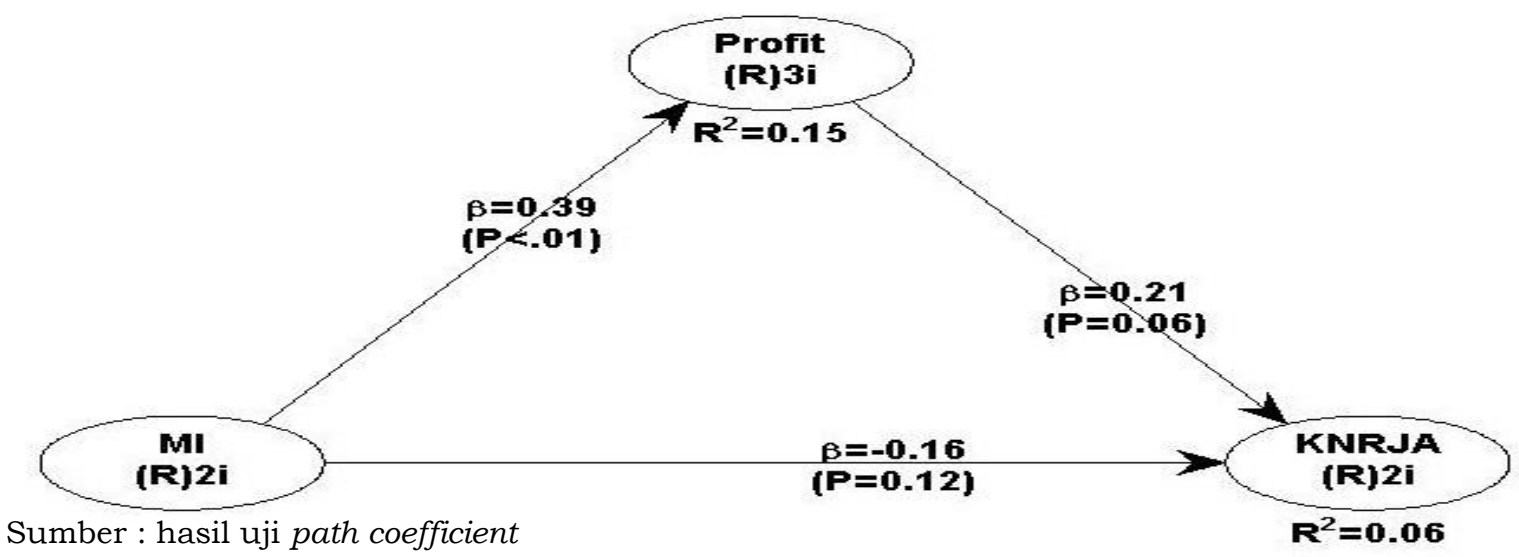

Gambar 2

Ouput Hasil Estimasi (Model 1) 


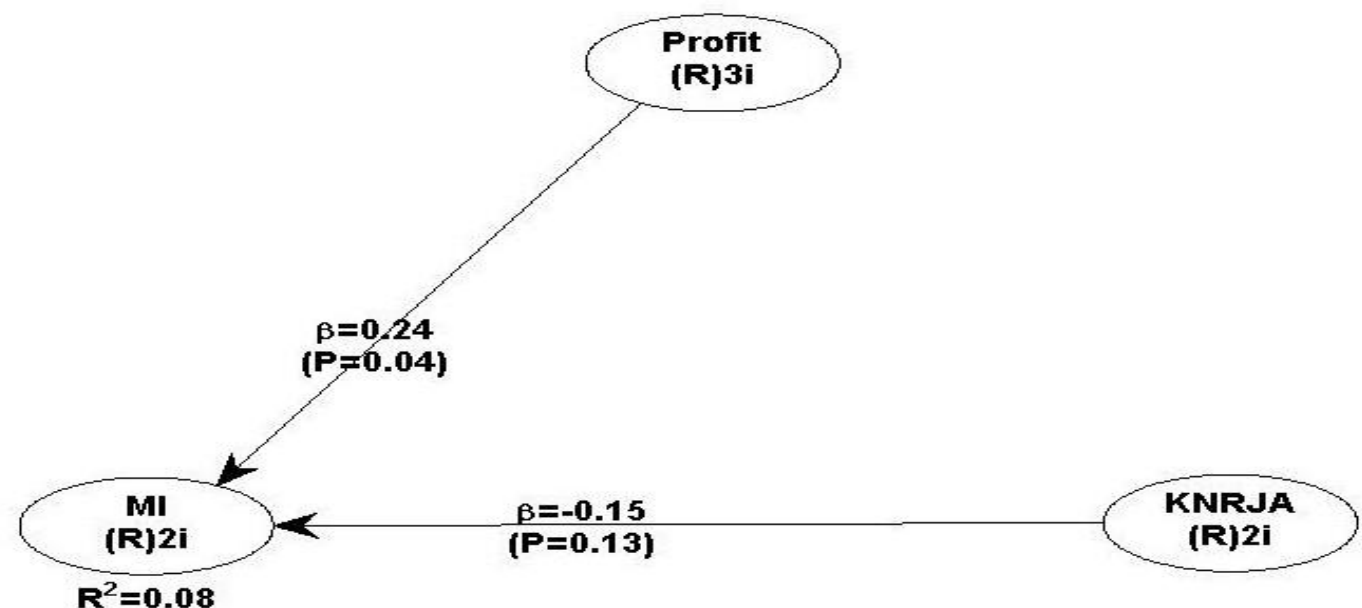

Sumber : Data diolah dengan WarpPLS 6.0

Gambar 3

Ouput Hasil Estimasi (Model 2)

Tabel 3

Hasil estimasi path coefficients

\begin{tabular}{lccc}
\multicolumn{1}{c}{ Hipotesis } & $\begin{array}{c}\text { Path } \\
\text { coefficients }\end{array}$ & p-value & Keterangan \\
Modal inti terhadap profitabilitas (H1) & 0,388 & 0.001 & Siginifikan \\
Profitabilitas terhadap modal inti (H2) & 0,239 & 0.038 & Siginifikan \\
Modal inti terhadap kinerja (H3) & $-0,159$ & 0,124 & Tidak Siginifikan \\
Kinerja terhadap modal inti (H4) & $-0,153$ & 0,133 & Tidak signifikan \\
Profitabilitas terhadap Kinerja (H5) & 0,209 & 0,062 & Tidak signifikan
\end{tabular}

Sumber : Data dokumentasi dari website diolah dengan program PLS

\section{Pembahasan}

Modal Inti yang terdiri atas CAR dan modal inti tambahan bepengaruh signifikan terhadap profitabilitas yang diukur dari Net interest income dan ROA dengan koefisien jalur bertanda positif. Semakin tinggi nilai CAR maka akan meningkatkan profitabilitas dari bank syariah. Pengungkapan nilai CAR menunjukkan kekuatan bank syariah dalam mengatasi kerugian, modal inti tambahan yang besar menunjukkan cakupan bank dalam melakukan kegiatan usaha cukup besar. Oleh karena itu aktivitas kegiatan bank yang ini diharapkan dapat menciptakan profitabilitas bank syariah yang semakin besar pula. Pernyataan tersebut sejalan dengan penelitian yang dilakukan oleh beberapa peneliti(Berger, A.N. , Herring, 1995); (Sussanto, 2007); (Ernasari, 2017) modal inti berpengaruh signifikan terhadap profitabilitas. Namun arahnya positif semakin besar modal inti semakin besar profitabilitas. 
Sebaliknya profitabilitas berpengaruh signifikan dan positif terhadap modal inti. Profitabilitas yang besar berarti nilai net interest marjin dan return on asset tinggi, akan menyebabkan kemampuan bank syariah dalam mencadangkan dana untuk kerugian (CAR) dan modal inti tambahan juga besar. Ketika bank syariah memiliki keuntungan yang besar, maka akan mencadangkan dana untuk keruguan dan untuk meperluas aktifitasnya menjadi semakin baik. Pernyataan tersebut sejalan dengan penelitian yang dilakukan oleh beberaapa peneliti (Kurniawan AT, Sudarto, 2014); (Ernasari, 2017) yang menyatakan bahwa profitabilitas berpengaruh signifikan terhadap modal inti.

Penelitian ini manyatakan bahwa modal inti tidak berpengaruh signifikan terhadap kinerja bank syariah. Seharusnya ketika CAR dan modal inti tambahan bank syariah tinggi, investor akan menangkap sinyal ini akan sebagai sebuah kekuatan yang akan meningkatkan kepercayaannya pada bank tersebut sehingga mengakibatkan harga saham bank tersebut menjadim tinggi. Namun yang terjadi adalah kestabilan nilai CAR dan nmodal inti tersebut tidak relevan dengan pasar modal. Investor dalam pasar modal tidak memerhatikan besarnya nilai modal inti, ini dikarenakan pasar modal bank syariah dapat menarik investor karena faktor eksternal, seperti tingkat kepatuhan terhadap hukum syariah. Besarnya modal inti bila tidak diikuti dengan aktifitas yang optimal dari perbankan tidak akan berdampak pada kinerja perbankan syariah itu sendiri. Pernyataan tersebut tidak sejalan dengan penelitian yang dilakukan oleh beberapa peneliti (Zuk-Butkuviene, 2014). Namun sesuai dengan penelitian dari Ernasari (2017) yang menyatakan modal inti tidak berpengaruh terhadap kinerja perbankan. Sebaliknya penelitian ini juga menyatakan kinerja bank syariah tidak berpengaruh signifikan terhadap modal inti. Pernyataan tersebut tidak sejalan dengan penelitian yang dilakukan oleh beberapa peneliti (Nazaf FL, 2014) dan (Ernasari, 2017) yang menyatakan bahwa kinerja berpengaruh signifikan terhadap modal inti. Kinerja bank syariah yang diukur dari harga pasar saham bank syarih ternyata tidak mempengaruhi kebijakan bank syariah tersebut dalam menetapkan besarnya nilai CAR dan modal inti tambahan yang dikelola. Harga pasar saham di Indonesia selain dipengaruhi oleh aspek internal, ternyata ada aspek eksternal yang menentukan variabilitas harga saham itu sendiri. Jadi tingkat kepatuhan (compliance) masyarakat pada hukum syariah, kondisi ekonomi global yang mewarnai pasar modal perbankan syariah saat ini (Ernasari, 2017).

Penelitian ini juga menunjukkan bahwa profitabilitas tidak berpengaruh terhadap kinerja bank syariah. Seharusnya semakin tinggi tingkat profitabilitas sebuah bank 
akan meningkatkan kinerja bank tersebut Ternyata Hasil penelitian ini berbeda dengan penelitian yang dilakukan oleh peneliti (Fathurrahman, 2012); (Ernasari, 2017) yang menyatakan bahwa profitabilitas berpengaruh terhadap kinerja. Adanya perbedaan hasil penelitian ini dengan penelitian sebelumnya adalah karena adanya perbedaan karakteristik dari pasar modal khususnya untuk bank syariah di Indonesia. Profitabilitas yang tinggi tidak akan mempengaruhi pasar modal perbankan syariah oleh karena investor juga melihat profitabilitas yang tinggi bukan merupakan satu satunya tujuan mereka untuk berinvestasi pada bank syariah. Tujuan semua investasi pada dasarnya adalah sama, yakni untuk mendapatkan keuntungan finansial berupa imbal hasil (return) dengan nilai yang setinggi mungkin. Hal ini juga berlaku untuk tujuan dari investasi syariah. Namun, pada tujuan investasi syariah, return bukanlah satusatunya hal yang menjadi tujuan utama. Sebab ada hal lain yang menjadi value dari investasi berbasis syariah ini, yaitu mengedepankan Socially Responsible Investment (Kurnia, 2021).

\section{KESIMPULAN}

Hasil penelitian ini menyimpulkan bahwa dari lima hipotesis yang diajukan hanya dua yang diterima yaitu Modal inti berpoengaruh signifikan terhadap rofitabilitas, dmikian sebaliknya profitabilitas juga berpengaruh signifikan terhadp modal inti. Penelitian ini menghasilkan bukti bahwa modal inti tidak berpengaruh signifikan terhadap kinerja bank syariah. Demikian juga ternyata Profitabilitas juga tidak signifikan mempengaruhi kinerja bank syariah, namun sebaliknya kinerja bank syariah tidak berpengaruh signifikan terhadap profitabilitas.

\section{IMPLIKASI PENELITIAN}

Kontribusi teoritis yang diberikan dalam penelitian ini adalah bahwa hasil penelitian yang berbeda dengan penelitian sebelumnya mengenai faktor modal inti dan profitabilitas terhadap kinerja keuangan justru ditolak dalam penelitian ini. Hal ini karena karakteristik pasar modal bank syariah yang berbeda dengan pasar keuangan lainnya. Perlu dikaji faktor eksternal lain seperti tingkat kepatuhan (compliance) masyarakat pada hokum syariah terhadap kinerja bank syariah, yang tidak diukur dalam penelitian ini.

Kontribusi manajerial yang diberikan dalam penelitian ini adalah bahwa manajemen bank syariah disarankan untuk lebih menggunakan tindakan akuntansi dalam mengirimkan sinyal positif terhadap pengguna laporan keuangan untuk meningkatkan kinerja perbankan syariah. Investor disarankan untuk melihat faktor faktor fundamental ketika menilai kinerja 
perbankan seperti Return on asset dan Return on equity, tidak hanya melihat kemampuan kekuatan bank dalam menutupi kerugian.

Penelitian selanjutnya dapat melengkapi model penelitian dengan menguji pengaruh kinerja bank terhadap profitabilitas. Penelitian selanjutnya juga dapat menguji variabel eksogen lain yang mempengaruhi kinerja perbankan syariah dari faktor eksternal, seperti tingkat kepatuhan (compliance) dari masyarakat.

\section{ACKNOWLEDGEMENT}

Ucapan terimakasih disampaikan kepada Universitas Wijaya Kusuma Surabaya yang mendukung pendanaan penelitian ini.

\section{DAFTAR PUSTAKA}

Abdillah W, H. (2015). Partial Least Square (PLS). Yogyakarta: Penerbit Andi.

Al-Tamimi KAM, S. O. (2013). Determinants of Capital Adequacy in Commercial Banks of Jordan an Empirical Study. International Journal of Academic Research in Economics and Management Science, 2(4).

Amelia, R. W., \& Nugrahani, C. (2018). Asset Scale and Capital Structure on The Performance of Sharia Banks, 1(2), 93-100.

Berger, A.N. , Herring, and S. (1995). The Role of Capital in Financial Institutions. Journal of Banking and Finance, 19.

Darmadji, Tjiptono, and H. M. F. (2001). Pasar modal di Indonesia: Pendekatan tanya jawab. Salembaempat.

Ernasari. (2017). Pengaruh Modal Inti,Manajemen Risiko dan Profitabilitas terhadap Kinerja. Universitas Brawijaya.

Fathurrahman. (2012). Pengaruh Tingkat Capital Adequacy ratio dan Loan to Deposit Ratio terhadap Profitabilitas pada PT Bank Sulselbar Makkasar. Universitas Hassanudin Makkasar.

Haryetti. (2012). Analisis Pengaruh Kinerja Keuangan Terhadap Harga Saham pada Perusahaan Perbankan. Jurnal Sosial Ekonomi Pembangunan, 3(7).

Ifham, A. (2010). Ekonomi Syariah. Jakarta: Gramedia Pustaka Utama.

Kiambati, M. P. (2019). International Journal of Social Science and Economic Research THE RELATIONSHIP BETWEEN CORE CAPITAL , LIQUIDITY , AND PROFITABILITY OF DEPOSIT-TAKING MICRO-FINANCE INSTITUTIONS IN KENYA, (April), 2623-2655.

Kurniawan AT , Sudarto, S. lestari. (2014). Analisis Faktor Faktor Yang Mempengaruhi Capital Adequacy Ratio. Purwokerto: Fakultas Ekonomi dan Bisnis Universitas Jendral Sudirman.

Lukman, D. (2003). Manajemen Perbankan (2nd ed.). Jakarta: Ghalia Indonesia. 
Mardian, S. (2015). Persepsi Masyarakat terhadap Penerapan Sharia Compliance Pada Bank Syariah di Kecamatan Barabai, 2(1), 45-58.

Naseer, S. (2019). CAPITAL UNIVERSITY OF SCIENCE AND Impact of Core Capital Ratio on Banks Profitability : Evidence from SAARC Countries by.

Nazaf FL. (2014). Pengeruh Kualitas Aset Likuiditas dan Profitabilitas Terhadap Tingkat kecukupan Modal Perbankan. Padang: Fakultas Ekonomi Universitas Negeri Padang.

Ongera, F. K., \& Ndede, F. W. S. (2019). Shariah Banking and Financial Performance of Selected Commercial Banks in Kenya, 3(Vi), 50-66.

https://doi.org/10.35942/ijcab.v3iVI.78

Salvatore, D. (2005). Ekonomi Manajerial dalam Perekonomian Global. Jakarta: Salemba Empat.

Soebiantoro, S. dan. (2007). Pengaruh Struktur Kepemilikan Saham,. Leverage, Faktor Interen dan Faktor Eksteren terhadap Nilai. Perusahan. Jurnal Manajemen Dan Kewirausahaan, 13(8).

Sugiyono. (2017). Metode Penelitian Kuantitatif, Kualitatif, dan R\&D. Bandung: CV Alfabeta.

Sulistyastuti, D. R. (2005). No TitleAnalisis Pengaruh Earning perShare, Price earning Rasio dan Return on equity terhadap Harga Saham. Universitas Gunadarma.

Sussanto, I. (2007). Analisis Pengaruh Modal Inti,Rasio Kecukupan Modal,Rasio Pinjaman Deposito,Kredit Macet dan Suku Bunga Bersih Terhadap Profitabilitas bank. Majalah Ekonomi Dan Komputer, 15(3).

Van Horne, W. (2005). Prinsip-prinsip Manajemen. Keuangan (12th ed.). Jakarta: Salemba Empat.

Widoatmodjo. (2009). Pasar Modal Indonesia: Pengantar dan Studi Kasus. Ghalia Indonesia.

William, N. (2013). THE IMPACT OF CORE CAPITAL ON THE PROFITABILITY OF COMMERCIAL BANKS IN KENYA BY PROJECT SUBMITTED IN PARTIAL FULFILLMENT OF THE REQUIREMENTS OF THE DEGREE OF MASTER OF BUSINESS ADMINISTRATION , UNIVERSITY OF NAIROBI NOVEMBER 2013, (November).

Zuk-Butkuviene. (2014). Capital Adequacy and Liquidity Risk Management. Ekonomika, 93(2).

\section{Situs}

Indonesia Investment .(2020).

https://www.indonesia investments.com/id/budaya/agama/islam/item248

Otoritas Jasa Keuangan.(2016). Statistik perbankan syariah. Komposisi Pembiayaan yang Diberikan BPRS di Indonesia. https://www.ojk.go.id/id/kanal/syariah/data-danstatistik/statistik-perbankan-syariah/Pages/Statistik-Perbankan-Syariah---Juni2016.aspx

Kunia, Dian Riza. (2021).

https://www.qoala.app/id/blog/keuangan/investasi/investasi-syariah/ 